\title{
New records and update on the geographic distribution of the Lontra longicaudis (Olfers, 1818) in the state of Rio Grande do Norte, Brazil
}

\author{
Izabela Costa Laurentino, Rafael Turíbio Moraes de Sousa, Gilberto Corso
}

Federal University of Rio Grande do Norte, Center of Biosciences, Postgraduate Program in Biological Sciences, Department of Biophysics and Pharmacology. University Campus Lagoa Nova, CEP 59078-970, PO Box 1524, Natal, Rio Grande do Norte, Brazil.

Corresponding author: Izabela Laurentino, izabelaurentino@gmail.com

\begin{abstract}
Lontra longicaudis (Olfers, 1818), Neotropical Otter, is a medium-sized, carnivorous, semi-aquatic mammal with a wide geographic distribution from Mexico to Uruguay. Although the number of studies on this species has been increasing, the vast majority of them focus on diet and habitat use. This paper updates the distribution of this species by providing new records from 19 municipalities (13 in the Atlantic Forest) in the state of Rio Grande do Norte. These new records are important for the conservation of $L$. longicaudis.
\end{abstract}

Keywords

Atlantic Forest, Environmental Protection Area, river basin, South America.

Academic editor: Alexandra Costa | Received 5 October 2019 | Accepted 10 January 2020 | Published 24 January 2020

Citation: Laurentino IC, Sousa RTM, Corso G (2020) New records and update on the geographic distribution of the Lontra longicaudis (Olfers, 1818) in the state of Rio Grande do Norte, Brazil. Check List 16 (1): 83-87. https://doi.org/10.15560/16.1.83

\section{Introduction}

Lontra longicaudis (Olfers, 1818), Neotropical Otter, is a medium-sized, semi-aquatic, carnivorous mammal of the family Mustelidae. It is widespread in Brazil where it occurs in almost all water bodies, such as rivers, streams, ponds, and estuaries (Eisenberg and Redford 2000; Rodrigues et al. 2013). Although found in a wide variety of freshwater and estuarine habitats, biological data is deficient due to its elusive behaviour (Sivasothi and Nor 1994). Despite its wide distribution from Mexico to Uruguay, the Neotropical Otter is classified as Near Threatened (Rheingantz and Trinca 2015).

Lontra longicaudis is also classified as Near Threatened in northeastern Brazil and Vulnerable in the Atlantic Forest domain due to the high level of habitat degradation (Rodrigues et al. 2013). Current records show that the population occurs in watersheds between the Caatinga and Atlantic Forest biomes (Rosas-Ribeiro et al. 2017). In the state of Rio Grande do Norte, the Atlantic Forest is a mosaic of forest and associated ecosystems, including dense and sparse ombrophylous forest, mangrove, resting, and seaboard. Currently, habitat fragmentation and water pollution are threats to L. longicaudis. The consequent habitat degradation has justified the suspicion that several L. longicaudis populations are declining (Melo 2013).

To better understand the distribution of L. longicaudis in the state of Rio Grande do Norte, we aim to fill knowledge gaps in the distribution and ecology of this species, mainly in an area of Atlantic Forest that remains poorly understood.

\section{Methods}

The study was made between 2017 and 2018 in the eight river basins (Ceará Mirim, Potengi, Pirangi, Trairi, Jacu, Catu, Guaju, and Curimataú) on the east coast of the 
state. The banks of the rivers were covered with the predominant vegetation of the Atlantic forest. We employed the database of the National Register of Conservation Units of the Ministry of the Environment (MMA 2015) to survey the conservation units at the federal, state, and municipal levels. We compiled this information with ArcGIS v. 10.1. Subsequently, we visited all reaches of the perennial rivers in the municipalities near the Atlantic Ocean. We conducted semi-structured interviews with the fisher communities along the rivers to obtain information about the occurrence of otters. We spent five days in each municipality and we worked approximately $5 \mathrm{~km}$ of the river each day. We completed 190 interviews, with 10 people from each municipality.

Based on the interviews, we looked for direct and indirect signs of the otter. The main signs of the presence of otters were carcasses, faeces, footprints, claw marks, and latrines. Depending on the habitat conditions, the river stretches were surveyed using an outboard motor boat (speed controlled $\leq 7 \mathrm{~km} / \mathrm{h}$ ), by kayaking, or by walking along the trails. During the fieldwork we used a camera, binoculars, and GPS receiver. Trap camera were placed near coves, trails, or fresh latrines to obtain photographic records of the species. Our study was authorized under the license ICMBio no. 32910-5.

\section{Results}

New records. Brazil: Rio Grande do Norte • hydrographic basin of Ceará Mirim, Ceará-Mirim Municipality $\left(05^{\circ} 38^{\prime} 16^{\prime \prime} \mathrm{S}, 035^{\circ} 23^{\prime} 03^{\prime \prime} \mathrm{W}\right)$, May 2017 , carcass and faeces (Fig. 1A) - same basin, Extremoz Municipality $\left(05^{\circ} 42^{\prime} 19^{\prime \prime} \mathrm{S}, 035^{\circ} 16^{\prime} 48^{\prime \prime} \mathrm{W}\right)$, June 2017 , carcass and faeces (Fig. 1H) • same basin, São Gonçalo do Amarante Municipality $\left(05^{\circ} 47^{\prime} 35^{\prime \prime} \mathrm{S}, 035^{\circ} 19^{\prime} 22^{\prime \prime} \mathrm{W}\right)$, July 2017 , carcass and faeces (Fig. 1D) • hydrographic basin of Potengi, Macaíba Municipality $\left(05^{\circ} 52^{\prime} 04^{\prime \prime} \mathrm{S}, \quad 035^{\circ} 27^{\prime} 41^{\prime \prime} \mathrm{W}\right)$, August 2017, carcass and faeces (Fig. 1B) • hydrographic basin of Pirangi, Parnamirim Municipality $\left(05^{\circ} 59^{\prime} 04^{\prime \prime} \mathrm{S}\right.$, $035^{\circ} 07^{\prime} 39^{\prime \prime} \mathrm{W}$ ), September 2017, faeces, anal mucus, and records by camera trap (Fig. 1E) • same basin, Nísia Floresta Municipality $\left(06^{\circ} 07^{\prime} 23^{\prime \prime} \mathrm{S}, 035^{\circ} 07^{\prime} 32^{\prime \prime} \mathrm{W}\right)$, October 2017, faeces and records by camera trap (Fig. 1F) • hydrographic basin of Trairi • São José de Mipibu Municipality $\left(06^{\circ} 66^{\prime} 04^{\prime \prime} \mathrm{S}, 035^{\circ} 15^{\prime} 30^{\prime \prime} \mathrm{W}\right)$, November 2017 , faeces and records by camera trap (Fig. 1G) - hydrographic basin of Catu, Senador Georgino Avelino Municipality
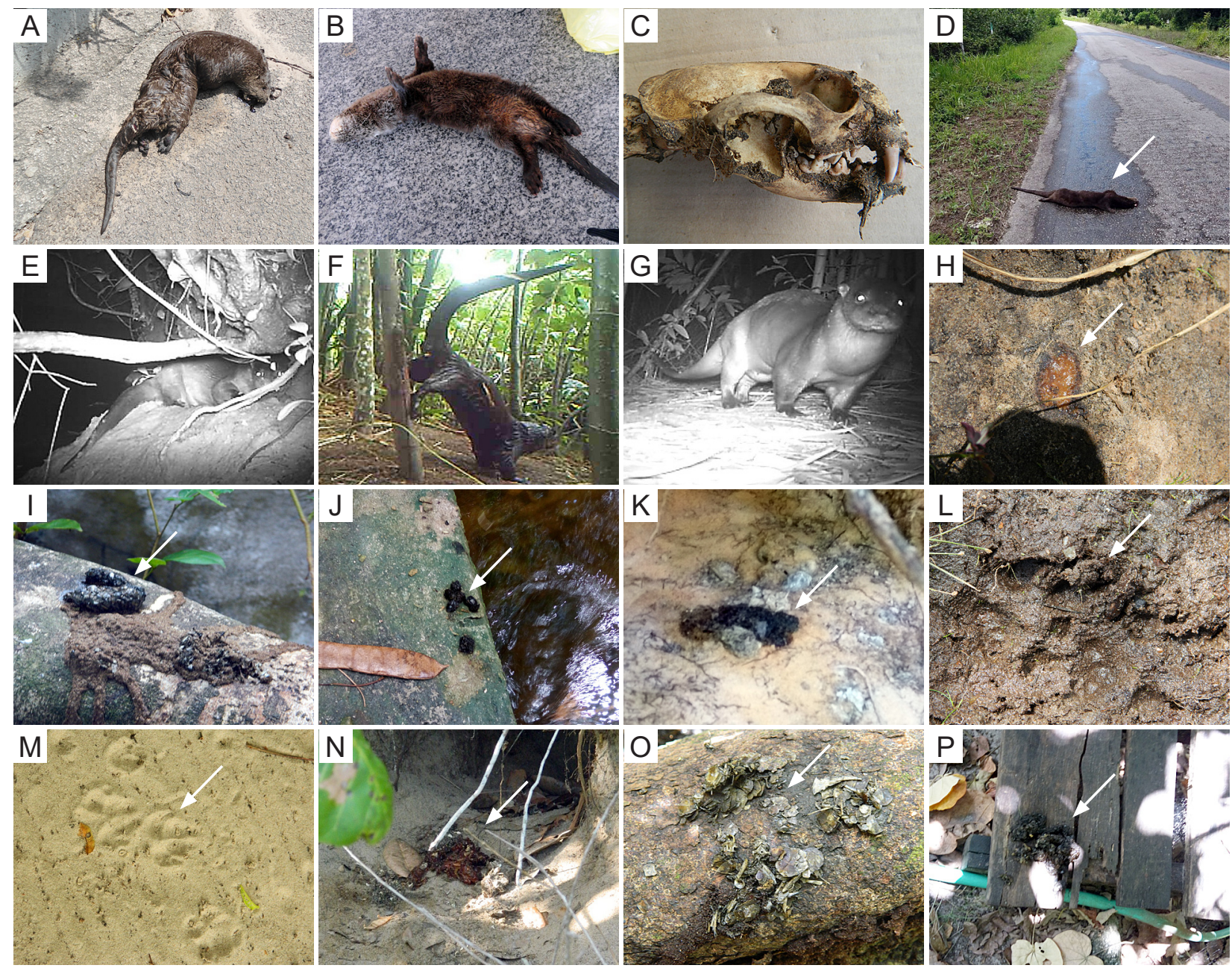

Figure 1. Records of Lontra longicaudis $(A-G)$ and faeces with anal mucus and footprints (H-P) by counties. A. Ceará-Mirim. B. Macaiba. C. Tibau do Sul. D. São Gonçalo do Amarante. E. Parnamirim. F. Nísia Floresta. G. São José de Mipibu. H. Extremoz. I. Senador Georgino Avelino. J. Arês. K. Goianinha. L. Pedro Velho. M. Canguaretama. N. Montanhas. O. Baia Formosa and P. Vila Flor. 
$\left(06^{\circ} 08^{\prime} 46^{\prime \prime} \mathrm{S}, 035^{\circ} 09^{\prime} 15^{\prime \prime} \mathrm{W}\right)$, December 2017 , faeces and footprints (Fig. 1I) • Arês Municipality $\left(06^{\circ} 12^{\prime} 19^{\prime \prime} \mathrm{S}\right.$, $035^{\circ} 08^{\prime} 52^{\prime}$ 'W), January 2018 , faeces and footprints (Fig. $1 \mathrm{~J}) \cdot$ same basin, Tibau do Sul Municipality $\left(06^{\circ} 16^{\prime} 58^{\prime \prime} \mathrm{S}\right.$, $035^{\circ} 02^{\prime} 43^{\prime \prime} \mathrm{W}$ ), February 2018, carcass and faeces (Fig. 1C). • same basin, Vila Flor Municipality (06²19'37"S, $035^{\circ} 05^{\prime} 10^{\prime \prime} \mathrm{W}$ ), March 2018, faeces and footprints (Fig. 1P) • hydrographic basin of Guaju, Baia Formosa Municipality $\left(06^{\circ} 27^{\prime} 17^{\prime \prime} \mathrm{S}, 035^{\circ} 58^{\prime} 48^{\prime \prime} \mathrm{W}\right)$, April 2018, faeces (Fig. 1O) • hydrographic basin of Curimatau, Canguaretama Municipality $\left(06^{\circ} 24^{\prime} 52^{\prime \prime} \mathrm{S}, 035^{\circ} 11^{\prime} 09^{\prime \prime} \mathrm{W}\right)$, May 2018 , carcass, faeces and footprints (Fig. 1M) - same basin, Pedro Velho Municipality $\left(06^{\circ} 25^{\prime} 05^{\prime \prime} \mathrm{S}, 035^{\circ} 13^{\prime} 50^{\prime \prime} \mathrm{W}\right)$, June 2018, faeces and footprints (Fig. 1L) • same basin, Montanhas Municipality $\left(06^{\circ} 28^{\prime} 20^{\prime \prime} \mathrm{S}, 035^{\circ} 16^{\prime} 16^{\prime \prime} \mathrm{W}\right)$, July 2018, faeces and footprints (Fig. 1N) • hydrographic basin of Jacu, Goianinha Municipality $\left(06^{\circ} 15^{\prime} 15^{\prime \prime} \mathrm{S}\right.$, $035^{\circ} 13^{\prime} 04^{\prime \prime} \mathrm{W}$ ), August 2018, faeces (Fig. 1K). • Santo Antônio Municipality (06 19 '23'S, 035 26'57'W), September 2018, interviews, in which they affirm the existence of an otter. - same basin, São José do Campestre Municipality $\left(06^{\circ} 19^{\prime} 42^{\prime \prime} \mathrm{S}, 035^{\circ} 42^{\prime} 02^{\prime \prime} \mathrm{W}\right)$, June 2018, interviews, in which they affirm the existence of an otter. - same basin, Passagem Municipality $\left(06^{\circ} 16^{\prime} 51^{\prime \prime} \mathrm{S}\right.$, $\left.035^{\circ} 23^{\prime} 52^{\prime \prime} \mathrm{W}\right)$, October 2018, interviews, in which they affirm the existence of an otter.

Identification. Lontra longicaudis (Olfers, 1818) belongs to the family Mustelidae, subfamily Lutrinae (Wozen- craft 2005). The species is distributed in Central and South America, from northwestern Mexico to Uruguay (Emmons 1990; Chehébar 1990; Chebez 1999; Eisenberg and Redford 1999). It is a medium-sized animal with an elongated body and a dense, short coat of general brownish-brown color, slightly lighter in the ventral region, especially in the throat (Bertonatti and Parera 1994). It is a species of semi-aquatic habit and, therefore, has some morphological adaptations for locomotion in water, such as paws with interdigital membranes, slightly flattened long tail and large vibrissae (Emmons 1990; Silva 1994).

Nineteen new records of $L$. longicaudis were obtained in the municipalities along the eastern coast of Rio Grande do Norte and confirm the results of Laurentino and Sousa (2014) and Rosas-Ribeiro et al. (2017) who found this species in 15 municipalities. We confirmed the occurrence records of $L$. longicaudis in all eight river basins studied. In addition, we found the first records from four municipalities: Arês, Goianinha, São Gonçalo do Amarante and Tibau do Sul. In totaling $L$. longicaudis was found in 19 studied municipalities, including 13 in the Eastern Littoral of the Atlantic Forest area domain (Fig. 2).

The Lontra longicaudis was identified using previous studies in the state of Rio Grande do Norte. The first record of the species was by Laurentino and Sousa (2014) in the municipalities of Baia Formosa, Canguaretama, Ceará-Mirim, Extremoz, Macaíba, Nísia Floresta, Parnamirim, Pedro Velho, Senador Georgino Avelino,

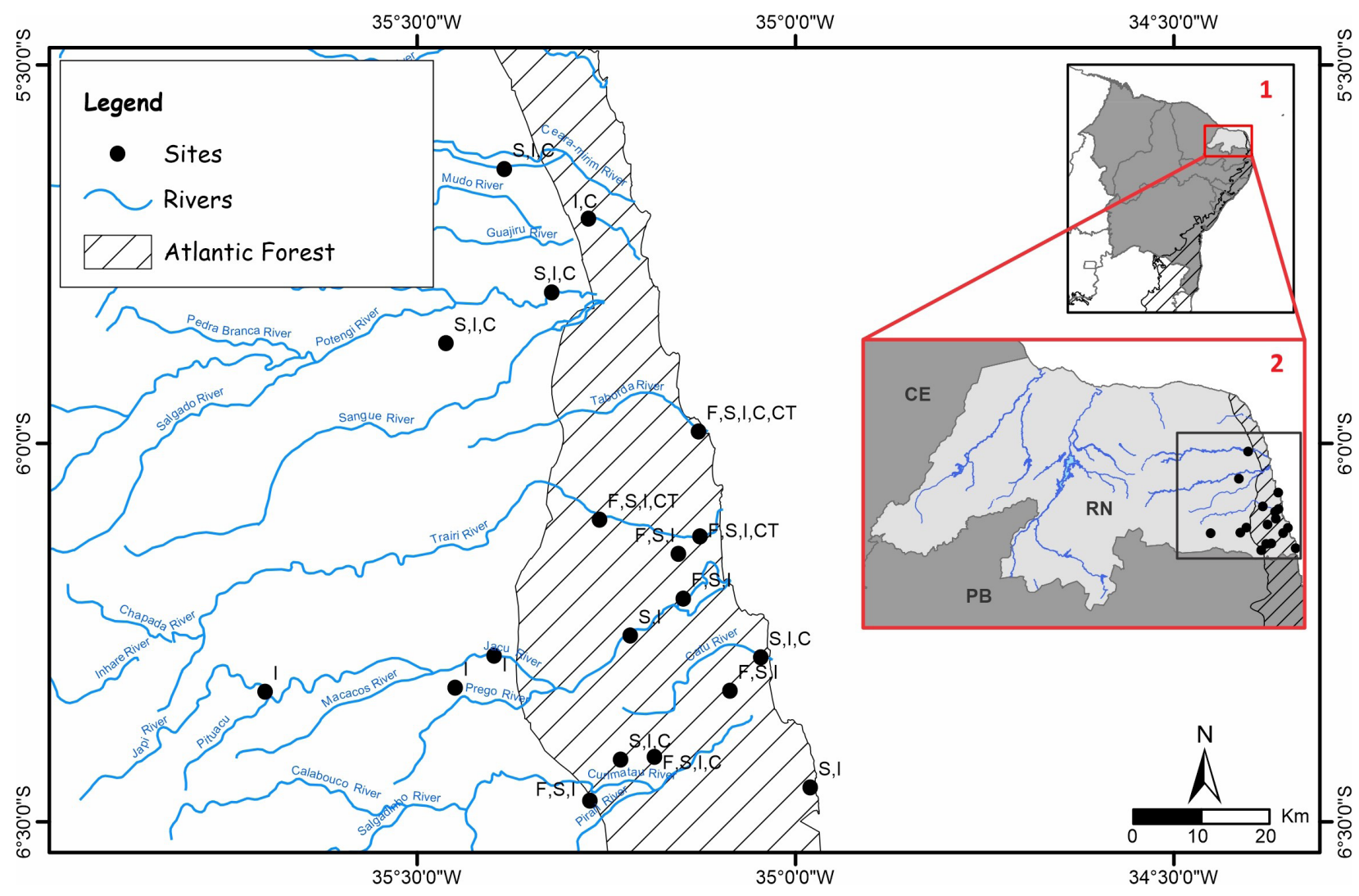

Figure 2. Records of Lontra longicaudis (Olfers, 1818), within (1) northeastern Brazil and (2) the state of Rio Grande do Norte. Occurrence in the municipalities of Rio Grande do Norte, watersheds with a predominance of Atlantic forest. Record type: $\mathrm{C}=$ carcass; $\mathrm{CT}=$ camera trap; $\mathrm{F}=$ footprints; I = interviews; $\mathrm{S}=$ signs (latrines and anal mucus). 
and Vila Flor. Rosas-Ribeiro et al. (2017) later updated the records in the Brazilian Northeast Region and confirmed the presence of L. longicaudis in Rio Grande do Norte in the municipalities of Macaíba, São José de Mipibu, Passagem, Santo Antônio, São José do Campestre, and Montanhas.

\section{Discussion}

According to Pardini and Trajano1999; Waldemarin and Colares 2000; and Quadros and Monteiro-Filho 2002, Lontra longicaudis has marks its territory with faeces and anal mucus, which serve as scent marks and indicate the presence of otters. In the latrines of otters, the dried faeces are frequently observed with fish scales and crustacean remains. The undigested scales that remain in the dark and dry faeces facilitated the identification of faeces as beinging to L. longicaudis (Laurentino et al. 2019).

Faeces were sometimes deposited together with anal mucus. The excretion of only anal mucus by be used by other otters in the same territory to distinguish sex and whether females are pregnant or have young (Teixeira et al. 2008).

We obtained records of the active period of the $L$. longicaudis with the photographic traps. The records revealed, mainly solitary, twilight, and nocturnal habits (Fonseca et al. 1984). However, we also individuals interacting with others of the same species, probably pups or mating partners. Photographic traps were useful in that the species has nocturnal habits and is shy, and they allowed for the monitoring of several points simultaneously (Silva 2016). In addition, there were daytime records of dead otters found along roads near houses near or on riverbanks.

Six municipalities where $L$. lonicaudis were recorded are within the Bonfim-Guaraíras Environmental Protection Area (Tibau do Sul, Goianinha, Arês, Senador Georgino Avelino, Nísia Floresta and São José de Mipibu) and three in the Piquiri-Una Environmental Protection Area (Goianinha, Canguaretama, and Pedro Velho). Moreover, some records were found in five municipalities in the transition area from Atlantic Forest to Semiarid region (Santo Antônio, São José do Campestre, Passagem, Pedro Velho, and Montanhas).

Population size studies of L. longicaudis are difficult to perform due to the difficulty of observing this elusive species, which is nocturnal and have territories. According to Dietrich (1995), the combination of photographic traps, searches for trails, and interviews in the local community have proved to be satisfactory because they provide integrated data. Two studies have suggested that L. longicaudis may tolerate human activities, depending on the size of the altered area and the presence of preserved areas in their proximity (Pardini and Trajano 1999; Kasper 2008).

Conservation areas are generally extensive and regulate human activity through management plans; they aim to promote the conservation of natural resources and maintain environmental quality for the local communities (Rylands and Brandon 2005). With the increase in human habitation in Rio Grande do Norte, there ecosystems have been affected and the Atlantic Forest has been reduced to fragments and secondary remnants. Considering that there are no differences among Atlantic Forest vegetation within the seven river basins, we believe that the intensity of use of otter marking sites is related to the vegetation coverage of the sites, with the most used sites having more abundant vegetation coverage. This is corroborated elsewhere in Brazil, where L. longicaudis was found to prefer preserved forests and river stretches with abundant vegetation (Waldemarin and Colares 2000, 2002; Alarcon and Simões-Lopes 2003). However, vegetation cover only partially explains the use of the space by this species, considering that the marking occurred in more preserved areas. We highlights the need for additional studies to identify the factors, such as the location of shelters, the degree of vegetation coverage, and the degree of anthropization, that influence the use of space by L. longicaudis.

\section{Acknowledgements}

We acknowledge the Coordination Improvement Folks Higher Level (CAPES), for the scholarship granted to the students of the Postgraduate Program in Biological Sciences of the Federal University of Rio Grande do Norte. We are grateful to Robert Forsyth for helping revise the manuscript.

\section{Authors' Contributions}

ICL and RTMS designed the sampling procedures and conducted the data analyses, ICL and RTMS conducted field campaigns for data collection, GC contributed to the image analyses and revised the manuscript, and ICL wrote the manuscript.

\section{References}

Alarcon GG, Simões-Lopes PC (2003) Preserved versus degraded coastal environments: a case study of the Neotropical Otter in the Environmental Protection Area of Anhatomirim, southern Brazil. Otter Specialist Group Bulletin 20 (1): 6-18.

Bertonatti C, Parera A (1994) Lobito de rio. Wild Life Magazine, nuestro Libro Rojo. Fundación Vida Silvestre Argentina, Ficha $n^{\circ} 34$.

Chebez JC (1999) Los que se van: espécies argentinas em peligro. Editorial Albatroz Saci, Buenos Aires, 606 pp.

Chehébar CE (1990) Action plan from Latin American otters. In: Foster-Turley P, Macdonald Sand Mason C (Eds) Otters: a plan for their conservation. IUCN Otter Specialist Group Bulletin: 64-73.

Dietrich JR (1995) El uso de entrevistas para averiguar la distribución de vertebrados. Revista de Ecología Latino Americana 2 (1-3): $1-4$.

Eisenberg JF, Redford KH (1999) Mammals of the Neotropics. Vol. 3. The central tropics: Ecuador, Peru, Bolivia, Brazil. University of Chicago Press, Chicago, 609 pp.

Emmons LH (1990) Neotropical Rainforest Mammals: a field guide. University of Chicago Press, Chicago: 281 pp. 
Fonseca GA, Rylands AB, Costa CM, Machado RB, Leite YLR (1984) Livro Vermelho da fauna brasileira ameaçada de extinção. http:// www.icmbio.gov.br/portal/images/stories/biodiversidade/faunabrasileira/livro-vermelho/volumeI/vol I parte2.pdf. Accessed on: 2019-01-07.

Kasper CB, Bastazini VAG, Salvi J, Grillo HCZ (2008) Trophic ecology and the use of shelters and latrines by the Neotropical Otter (Lontra longicaudis) in the Taquari Valley, southern Brazil. Iheringia. Série Zoologia 98 (4): 469-474. https://doi.org/10. 1590/S0073-47212008000400009

Laurentino IC, Sousa RTM (2014) Unpublished occurrence of the Lontra longicaudis (Olfers 1818) in the state of Rio Grande do Norte, Brazil. Electronic Journal of Biology 7 (4): 458-474.

Laurentino IC, Sousa RTM, Corso G, Sousa-Lima R (2019) To eat or not to eat: ingestion and avoidance of fecal content from communal latrines of Lontra longicaudis (Olfers, 1818). Latin American Journal of Aquatic Mammals 14 (1): 2-8.

Melo DDC (2013) Underwood bird communities of Atlantic Forest forest remnants of northeastern Brazil: composition, diversity and habitat. https://repositorio.ufpb.br/jspui/handle/tede/4142. Accessed on: 2019-01-05.

MMA (2010) Conservation overview of coastal and marine ecosystems in Brazil. http://www.mma.gov.br/publicacoes/biodiversidade/ category/53-biodiversidade-aquatica?download=21:panoramada-conservacao-dos-ecossistemas-costeiros-e-marinhos-nobrasil. Accessed on: 2019-03-02.

Pardini R (1998) Feeding ecology of the neotropical river otter Lontra longicaudis in an Atlantic Forest stream, south-eastern Brazil. Journal of Zoology 245 (4): 385-391. https://doi.org/10.1017/S 0952836998008024

Pardini R, Trajano E (1999) Use of shelters by the Neotropical River Otter (Lontra longicaudis) in an Atlantic forest stream, southeastern Brazil. Journal of Mammalogy 80 (2): 600-610. https://doi. org/10.2307/1383304

Quadros J, Monteiro-Filho ELA (2002) Sprainting sites of the Neotropical Otter, Lontra longicaudis, in an Atlantic Forest area of southern Brazil. Journal of Neotropical Mammalogy 9 (1): 39-46. https://doi.org/10.1076/snfe.36.1.15.8881

Quintela FM, Ibarra C, Colares EP (2011) Utilization of shelters and latrines by Lontra longicaudis (Olfers, 1818) in a coastal stream in the Lagoa Verde Environmental Protection Area, Rio Grande do Sul, Brazil. Neotropical Biology and Conservation 6 (1): 35 43. https://doi.org/10.4013/nbc.2011.61.05

Rheingantz ML, Trinca CS (2015) Lontra longicaudis. The IUCN Red List of threatened species 2015: e.T12304A21937379. https://doi. org/10.2305/iucn.uk.2015-2.rlts.t12304a21937379.en. Accessed on: 2019-03-02.

Rodrigues AL, Leuchtenberger C, Kasper CB, Junior OC, Silva VCF (2013) Assessment of the extinction risk of the Neotropical Otter Lontra longicaudis (Olfers, 1818) in Brazil. Brazilian Biodiversity (1): 216-227.

Rosas-Ribeiro P, Ranulpho R, Venticinque E (2017) New records and update on the geographic distribution of Lontra longicaudis (Olfers, 1818) (Carnivora: Mustelidae) in seasonally dry tropical forests of northeastern Brazil. Check List 13 (3): 2108. https://doi. org/10.15560/13.3.2108

Rylands AB, Brandon K (2005) Brazilian protected areas. Conservation Biology 19 (3): 612-618. https://doi.org/10.1111/j.1523-1739. 2005.00711.x

Silva F (1994) Mamíferos silvestres do Rio Grande do Sul. Fundação Zoobotânica do Rio Grande do Sul, Porto Alegre: 246 pp.

Silva DA (2016) Medium and large mammalian community in forest fragments of Southern Amazon. Masters dissertation. Mato Grosso University, Brasil, 99 pp.

Sivasothi N, Nor BHM (1994) A review of otters (Carnivora: Mustelidae: Lutrinae) in Malaysia and Singapore. In: Sasekumar A, Marshall N, Macintosh JD (Eds) Ecology and conservation of Southeast Asian marine and freshwater environments including wetlands. Hydrobiologia 285: 151-170. https://doi.org/10.1007/ 978-94-011-0958-1_16

Teixeira MB, Dornelles RC, ÁvilaMC, Kerber LR, Koenemann JG (2008) Occurrence records of Lontra longicaudis (Olfers, 1818) in southwest Rio Grande do Sul, Brazil. Biodiversidade Pampeana 6 (2): 74-78.

Waldemarin HF, Colares EP (2000) Utilisation of resting sites and dens by the Neotropical River Otter (Lontra longicaudis) in the south of Rio Grande do Sul state, southern Brazil. IUCN Otter Specialist Group Bulletin 17 (1): 14-19.

Wozencraft WC (2005) Order Carnivora. In: Wilson DE, Reeder DM (Eds) Mammal species of the world: a taxonomic and geographic reference. 3rd Edition. The Johns Hopkins University Press, Baltimore, 532-628. 